JKM (Jurnal Kebidanan Malahayati),Vol 7,No.4.Oktober 2021,

ISSN (Print) 2476-8944 ISSN (Online) 2579-762X, Hal 851-856

\title{
RIWAYAT STATUS IMUNISASI DASAR BERHUBUNGAN DENGAN KEJADIAN BALITA STUNTING
}

\author{
Yosintha Dilina Wanda ${ }^{1 *}$, Fardila Elba ${ }^{2}$, Didah ${ }^{3}$, Ari Indra Susanti ${ }^{4}$, Fedri Ruluwedrata Rinawan ${ }^{5}$ \\ 1Program Studi Diploma IV Kebidanan Fakultas Kedokteran Universitas Padjadjaran \\ 2Departemen IImu Kesehatan Masyarakat, Fakultas Kedokteran, Universitas Padjadjaran \\ ${ }^{*}$ Korespondensi email yosinthana70@gmail.com
}

\section{ABSTRACT HISTORY OF BASIC IMMUNIZATION STATUS ASSOCIATED WITH THE EVENT OF STUNTING TODDLERS}

Background: According to the World Health Organization (WHO) 2018, the prevalence of stunting in Indonesia is the third country with the highest prevalence in the Southeast Asia Region (SEAR). The average prevalence of children under five in Indonesia in 2005-2017 was 36.4\%. In West Java the incidence of stunting is $29.9 \%$ and in Sumedang Regency the figure is still quite high at $36 \%$, and based on data from the Jatinangor Health Center in 2020 there are 60 stunting toddlers.

Purpose: The purpose to analyze the relationship between the history of basic immunization status and the incidence of in toddler in Hegarmanah Village, Jatinangor District in 2020.

Methods: This research design is a quantitative research conducted in Hegarmanah Village in November. This study use a case control design with a ratio of 1:1. The case group of this study was stunting and the control group was non-stunted. The groups of stunting and non-stunted toddlers were determined by a matching system of age and gender categorization. Sampling used proportionate stratified random technique. The sample in this study were stunted and non-stunted toddlers with a total sample of 120 respondents, 60 case groups and 60 control groups. The research instrument is a questionnaire and a microtoise to measure height. Bivariate analysis was carried out with Chi-Square and Odds Ratio tests

Results: The results showed that 30 (25\%) stunting toddlers aged 24-<36 months, 23 (19\%) toddlers aged $24-<36$ months and $19(16 \%)$ boys with a history of incomplete basic immunization status . Bivariate analysis was carried out with Chi-Square and Odds Ratio tests with a 95\% confidence level obtained $(p=0.000)$ with $O R$ and $\mathrm{Cl}$ (4.958 (2.074-11.852)). This states that there is a relationship between the history of basic immunization status on the incidence of stunting under five in Hegarmanah Village, Jatinangor District.

Conclusion: There is a relationship between the history of basic immunization status on the incidence of stunting in toddlers in Hegarmanah Village, Jatinangor District with a value of $p<0.05(p=0.00<0.05)$ and there is a risk of stunting in toddlers with incomplete immunization 4.9 times compared to toddlers with complete immunization.

Suggestion Future researchers are expected to be able to further investigate what types of immunization can affect stunting.

Keywords: Relationship, Stunting, Basic Immunization, Toddler

\section{ABSTRAK}

Latar Belakang: Menurut World Health Organization (WHO) data prevalensi kejadian stunting Indonesia termasuk negara ketiga dengan prevalensi tertinggi di regional Asia Tenggara /South-East Asia Regional (SEAR). Rata-rata prevalensi balita di Indonesia tahun 2005-2017 adalah 36,4\%. Di Jawa Barat angka kejadian stunting yaitu $29,9 \%$ dan di Kabupaten Sumedang angkanya masih cukup tinggi yaitu sebesar $36 \%$, dan berdasarkan data Puskesmas Jatinangor pada tahun 2020 terdapat 60 balita stunting.

Tujuan: Menganalisis hubungan riwayat status imunisasi dasar dengan kejadian balita stunting di Desa Hegarmanah Kecamatan Jatinangor Tahun 2020.

Metode: Rancangan penelitian ini merupakan penelitian kuantitatif yang dilakukan di Desa Hegarmanah pada Bulan November. Penelitian ini menggunakan desain case control dengan perbandingan 1:1. Kelompok kasus penelitian ini yaitu stunting dan kontrol yaitu non stunting. Kelompok balita stunting dan non stunting ditentukan dengan sistem matching kategorisasi usia dan jenis kelamin. Pengambilan sampel menggunakan teknik proportionate stratified random. Sampel dalam penelitian ini adalah balita yang stunting dan non stunting dengan jumlah sampel 120 responden, sebanyak 60 kelompok kasus dan 60 kelompok kontrol. Instrumen 


\section{Yosintha Dilina Wanda, Fardila Elba, Didah, Ari Indra Susanti,Fedri Ruluwedrata Rinawan}

penelitian ini yaitu kuisioner dan microtoise untuk mengukur tinggi badan. Analisis bivariate dilakukan uji ChiSquare dan Odds Ratio

Hasil: Hasil penelitian didapatkan $30(25 \%)$ balita stunting dengan usia 24-<36 bulan, 23 (19\%) balita usia $24-<36$ bulan dan 19 (16\%) balita laki-laki dengan riwayat status imunisasi dasar yang tidak lengkap. Analisis bivariate dilakukan uji Chi-Square dan Odds Ratio dengan tingkat kepercayaan $95 \%$ didapatkan $(p=0,000)$ dengan $\mathrm{OR}$ dan $\mathrm{Cl}(4,958$ (2,074-11,852)).

Kesimpulan: Terdapat hubungan antara riwayat status imunisasi dasar pada kejadian balita stunting di Desa Hegarmanah Kecamatan Jatinangor dengan nilai $p<0,05 \quad(p=0.00<0.05)$ serta terdapat risiko kejadian stunting pada balita dengan imunasi tidak lengkap 4,9 kali dibanding balita dengan imunisasi yang lengkap.

Saran Peneliti selanjutnya diharapkan dapat meneliti lebih lanjut mengenai jenis imunisasi apa yang dapat mempengaruhi stunting.

Kata kunci : Hubungan, Stunting, Imunisasi Dasar, Balita

\section{PENDAHULUAN}

Data prevalensi balita stunting menurut World Health Organization (WHO) 2018, Indonesia termasuk ke dalam negara ketiga dengan prevalensi tertinggi di regional Asia Tenggara ISouth-East Asia Regional (SEAR). Rata-rata prevalensi balita stunting di Indonesia tahun 20052017 adalah $36,4 \%$. Hasil riset studi status gizi balita Indonesia (SSGBI) 2019 mencatat bahwa jumlah balita stunting di Indonesia saat ini mencapai 27,67\%.1 Pada tahun 2018, menurut data Riset Kesehatan Dasar (Riskesdas) angka kejadian stunting di Indonesia $29,9 \%$, dengan kriteria sangat pendek yaitu sebesar $12,8 \%$ dan pendek sebesar $17,1 \% .^{2}$ Di Jawa Barat angka kejadian stunting yaitu $29,9 \%$, sedangkan di Kabupaten Sumedang angkanya masih cukup tinggi yaitu sebesar $36 \%$. Menurut Sekretariat Daerah Kabupaten Sumedang (2018) terdapat beberapa anak yang menderita stunting di Desa Hegarmanah ${ }^{3}$ Menurut data rekapitulasi hasil BPB tahun 2020 jumlah balita di Puskesmas Jatinangor sebanyak 3574 balita. Data stunting di Desa Hegarmanah sebesar 17,43\% dengan jumlah balita stunting sebanyak 60 balita dan yang normal 502 balita. Berdasarkan data tersebut, Desa Hegarmanah merupakan desa dengan angka kejadian stunting tertinggi di Kecamatan Jatinangor. ${ }^{4}$

Stunting menyebabkan penurunan kemampuan kognitif dan motorik serta penurunan performa kerja. Perkembangan kognitif berdampingan dengan proses pertumbuhan secara genetik atau kematangan fisik anak. Baik buruknya status gizi balita akan berdampak langsung pada pertumbuhan dan perkembangan kognitif dan psikomotorik anak. Anak stunting memiliki rerata skor Intelligence Quotient (IQ) sebelas poin lebih rendah dibandingkan rerata skor IQ pada anak normal, serta perkembangan mental kurang optimal dan status kesehatan pada anak sering terganggu yaitu peningkatan kerentaan anak terhadap penyakit baik menular maupun penyakit tidak menular seperti anak tumbuh menjadi dewasa yang rentan dengan penyakit obesitas, penyakit jantung koroner, hipertensi, dan osteoporosis. ${ }^{5}$

Menurut penelitian Adilla, dkk kondisi stunting dapat terjadi gangguan pada proses pematangan neuron otak serta perubahan struktur dan fungsi otak serta terdapat hubungan yang signifikan antara stunting dengan IQ sebagai salah satu tanda perkembangan otak, dimana skor IQ pada anak stunting lebih rendah dibandingkan dengan anak non stunting. Perkembangan kognitif berdampingan dengan proses pertumbuhan secara genetik atau kematangan fisik anak. Baik buruknya status gizi balita akan berdampak langsung pada pertumbuhan dan perrkembangan kognitif dan psikomotorik anak. ${ }^{6}$

Stunting pada anak dapat disebabkan dari beberapa faktor salah satunya imunisasi dasar yang tidak lengkap, sehingga menyebabkan anak mudah terserang infeksi. Anak yang mengalami infeksi jika dibiarkan maka akan beresiko menjadi stunting. Salah satu penyakit infeksi yang timbul akibat tidak diberikan imunisasi adalah campak. Imunisasi campak yang dapat mencegah penyakit campak disebabkan oleh virus Myxovirus Viridae Meaadalah sles yang dapat ditularkan melalui udara (percikan ludah) dari bersin atau batuk dan dapat menyebabkan komplikasi diare hebat sehingga menggangu sistem pencernaan. ${ }^{7}$

Menurut penelitian Ilham Syam, dkk terdapat hubungan antara riwayat imunisasi dengan kejadian kejadian stunting. Gizi kurang dan infeksi bermula dari lingkungan yang tidak sehat dan sanitasi yang buruk. Infeksi dapat menghambat reaksi imunologis yang normal menghabiskan energi tubuh. Balita yang tidak memiliki imunitas terhadap penyakit, maka akan lebih cepat kehilangan energi tubuh karena penyakit infeksi, sebagai reaksi pertama 


\section{JKM (Jurnal Kebidanan Malahayati),Vol 7,No.4.Oktober 2021, \\ ISSN (Print) 2476-8944 ISSN (Online) 2579-762X, Hal 851-856}

akibat adanya infeksi adalah menurunnya nafsu makan anak sehingga anak akan menolak makanan yang diberikan ibunya. Penolakan terhadap makanan berarti berkurangnya pemasukan zat gizi dalam tubuh anak. ${ }^{8}$ Menurut penelitian Resti Agustia, dkk imunisasi merupakan faktor risiko terhadap kejadian stunting dimana imunisasi dasar lengkap berisiko tiga kali lebih besar untuk menderita stunting dibandingkan dengan balita yang mendapatkan imunisasi dasar lengkap. ${ }^{9}$ Penelitian ini bertujuan untuk menganalisis hubungan riwayat status imunisasi dasar dengan kejadian balita stunting di Desa Hegarmanah Kecamatan Jatinangor.

\section{METODE PENELITIAN}

Penelitian ini merupakan jenis penelitian kuantitatif dengan desain kasus kontrol. Kasus dalam penelitian ini yaitu stunting dan kontrol yaitu non stunting.

Penelitian ini berlokasi di Desa Hegarmanah dengan jumlah sampel penelitian 120 responden yaitu 60 balita stunting dan 60 balita non stunting. Pengambilan sampel dilakukan dengan proportional stratified random sampling untuk balita stunting dan untuk sampel non stunting menyesuaikan dari balita stunting (1:1) dengan kriteria inklusi: Ibu dari balita yang dijadikan responden, berdomisili di Desa Hegarmanah, bersedia menjadi responden, balita berusia $\geq 24$ bulan sd 59 bulan pada saat pengambilan sampel, balita berdomisili di Desa Hegarmanah, balita bersedia menjadi subjek penelitian.

Pengambilan data penelitian dilaksanakan pada bulan November 2020 yang sebelumnya sudah dilakukan izin penelitian terlebih dahulu yang diperoleh dari dua instansi yaitu Dinas Kesehatan Kabupaten Sumedang dan Puskesmas Jatinangor. Penelitian ini telah mendapat izin etik dari Komite Etik Universitas Padjadjaran Bandung, Indonesia berdasarkan izin etik 1056/UN6.KEP/EC/ 2020 dengan nomor register 0120101151.

Pengambilan sampel diawali dengan melihat daftar stunting terlebih dahulu di Puskesmas Jatinangor selanjutnya mendatangi setiap rumah balita yang terdapat di Desa Hegarmanah dilakukan dengan cara door to door sampai memenuhi sampel yang dibutuhan, sebelum penelitian dilaksanakan peneliti melakukan informed consent terlebih dahulu jika ibu dan balita menyetujui maka dilanjutkan proses pengambilan data dengan mengukur tinggi badan balita untuk memastikan apakah balita stunting atau tidak serta melihat status imunisasi dasar balita di buku KIA.
Data dianalisis dengan analisis univariat untuk mengetahui gambaran distribusi frekuensi, analisis bivariat menggunakan uji chi square dan Odds Ratio.

\section{HASIL DAN PEMBAHASAN}

Hasil penelitian ini didapat dari 120 balita dengan kelompok kasus 60 balita dan kelompok kontrol 60 balita yang memenuhi kriteria inklusi. Pada semua subjek dilakukan pemeriksaan pengukuran tinggi badan dan melihat kelengkapan status imunisasai dasar pada buku KIA. Hasil disajikan dalam bentuk tabel distribusi frekuensi dan hubungan sebagai berikut:

Tabel 1

Distribusi Frekuensi Berdasarkan Karakteristik Balita Terhadap Stunting

\begin{tabular}{lcccc}
\hline \multirow{2}{*}{ Karakteristik } & \multicolumn{2}{c}{ Stunting } & \multicolumn{2}{c}{ Non Stunting } \\
\cline { 2 - 5 } & $\mathbf{N}$ & $\%$ & $\mathbf{n}$ & $\%$ \\
\hline Usia & & & & \\
$24-<36$ bulan & 30 & 25 & 29 & 24 \\
$36-<48$ bulan & 24 & 20 & 24 & 20 \\
$48-<59$ bulan & 6 & 5 & 7 & 5 \\
Jenis Kelamin & & & & \\
Laki-laki & 30 & 25 & 30 & 25 \\
Perempuan & 30 & 25 & 30 & 25 \\
\hline \multicolumn{1}{c}{ Total } & 60 & 100 & 60 & 100 \\
\hline
\end{tabular}

Berdasarkan tabel 1 terlihat bahwa kebanyakan balita berusia $24-<36$ bulan yang mengalami stunting sebanyak $30(25 \%)$ balita dengan jenis kelamin laki-laki dan perempuan dengan jumlah yang sama yaitu 30 balita yang mengalami stunting maupun non stunting.

Tabel 2.

Distribusi Frekuensi Berdasarkan Karakteristik Balita Terhadap Riwayat Status Imunisasi Dasar

\begin{tabular}{lcccc}
\hline \multirow{2}{*}{ Karakteristik } & \multicolumn{2}{c}{ Lengkap } & \multicolumn{2}{c}{ Tidak Lengkap } \\
\cline { 2 - 5 } & $\mathbf{N}$ & $\%$ & $\mathbf{n}$ & $\%$ \\
\hline Usia & & & & \\
$24-<36$ bulan & 37 & 30 & 23 & 19 \\
$36-<48$ bulan & 36 & 30 & 11 & 9 \\
$48-<59$ bulan & 10 & 8 & 3 & 2 \\
Jenis Kelamin & & & & \\
Laki-laki & 41 & 34 & 19 & 16 \\
Perempuan & 42 & 35 & 18 & 15 \\
\hline \multicolumn{1}{c}{ Total } & 60 & 100 & 60 & 100 \\
\hline
\end{tabular}

Berdasarkan table 2 terdapat balita dengan usia $24-<36$ bulan yang memiliki status imunisasi 
dasar tidak lengkap sebanyak $23(19 \%)$ balita. Jenis kelamin laki-laki sebanyak $19(16 \%)$ balita dan perempuan sebanyak $18(15 \%)$ balita dengan riwayat imunisasi tidak lengkap.

Tabel 3.

Hubungan Riwayat Status Imunisasi Dasar Pada Balita Stunting dan Non Stunting

\begin{tabular}{|c|c|c|c|c|c|c|c|c|}
\hline \multirow{3}{*}{$\begin{array}{l}\text { Riwayat Status } \\
\text { Imunisasi Dasar }\end{array}$} & \multicolumn{4}{|c|}{ Stunting } & \multirow{2}{*}{\multicolumn{2}{|c|}{ Total }} & \multirow{3}{*}{$P$} & \multirow{3}{*}{ OR (95\%) } \\
\hline & \multicolumn{2}{|c|}{ Kasus } & \multicolumn{2}{|c|}{ Kontrol } & & & & \\
\hline & $\mathrm{n}$ & $\%$ & $\mathbf{N}$ & $\%$ & $\mathbf{N}$ & $\%$ & & \\
\hline Tidak Lengkap & 28 & 23.5 & 9 & 7.5 & 37 & 31 & 0 & 4058 \\
\hline Lengkap & 32 & 26.5 & 51 & 42.5 & 83 & 69 & 0,000 & 4,958 \\
\hline Total & 60 & 50 & 60 & 50 & 120 & 100 & & \\
\hline
\end{tabular}

$p=p$ value Uji Chi-Square

Berdasarkan tabel 3 menunjukan $28(23,5 \%)$ balita stunting dan $9(7,5 \%)$ balita non stunting dengan riwayat status imunisasi dasar tidak lengkap, $32(26,5 \%)$ balita stunting dan 51 (42,5\%) balita non stunting dengan riwayat status imunisasi dasar lengkap. Berdasarkan Uji Chi- Square $(p=0,000)$ dengan $O R$ dan $\mathrm{Cl}(4,958 \quad(2,074-$ 11,852)). Tabel ini menunjukan terdapat hubungan yang bermakna antara riwayat status imunisasi dasar dengan kejadian balita stunting di Desa Hegarmanah Kecamatan Jatinangor dengan risiko empat kali lipat balita dengan imunisasi dasar yang tidak lengkap mengalami stunting.

\section{PEMBAHASAN}

\section{Karakteristik Balita berdasarkan Riwayat Status Imunisasi dan Kejadian Stunting}

Stunting merupakan kondisi dimana kekurangan gizi kronis yang dimulai sejak 1000 hari pertama kehidupan. ${ }^{25}$ Penyebab stunting baik secara langsung maupun tidak langsung dapat mempengaruhi terjadinya stunting. Menurut kajian penelitian sebelumnya bayi berat lahir rendah (BBLR), tinggi badan ibu $<150 \mathrm{~cm}$ dan riwayat status imunisasi dasar lengkap merupakan faktor yang berhubungan dengan stunting di Indonesia. ${ }^{10}$ Didukung oleh penelitian lain kelengkapan riwayat status imunisasi dasar merupakan faktor yang mempengaruhi kejadian stunting dengan memiliki risiko tiga kali lebih besar mengalami stunting 11 Jenis kelamin balita pada penelitian ini dominan pada jenis kelamin laki-laki. Jenis kelamin menentukan pula besar kecilnya kebutuhan gizi untuk seseorang. Laki-laki lebih banyak membutuhkan zat tenaga dan prote.n dibandingkan perempuan. Laki-laki lebih sanggup mengerjakan pekerjaan berat yang tidak biasa dilakukan perempuan. Selama masa bayi dan anak-anak, anak perempuan cenderung lebih rendah kemungkinannya menjadi stunting. Jenis kelamin dapat menentukan besaran kebutuhan gizi sehingga terdapat keterkaitan antara status gizi dan jenis kelamin. Perbedaan besarnya kebutuhan gizi tersebut dipengaruhi karena adanya perbedaan komposisi tubuh antara laki-laki dan perempuan. Sehingga jumlah asupan yang harus dikonsumsi pun lebih banyak. ${ }^{12}$ Jenis kelamin anak adalah faktor prediktor yang kuat dari stunting pada anak usia 0-23 bulan dan 0-59 bulan. ${ }^{13}$ Penelitian lain menunjukkan bahwa anak usia 12-23 bulan memiliki risiko yang lebih tinggi dibandingkan dengan anak usia 6-11 bulan. ${ }^{14}$ Jumlah anak stunting menurun seiring bertambahnya usia. Anakanak berusia di bawah 3 tahun lebih berisiko dibandingkan anak-anak berusia di atas 3 tahun ${ }^{15}$ Penelitian lain juga mendukung bahwa kejadian stunting paling banyak pada balita usia 25-36 bulan. ${ }^{16}$ Penelitian ini juga menemukan bahwa kejadian stunting banyak terjadi pada balita dengan jenis kelamin laki-laki dan usia diatas 23 bulan, Perbedaan jenis kelamin berkaitan dengan perilaku masyarakat misalnya lebih cenderung menyukai anak perempuan selain itu juga secara epidemiologis menyatakan bahwa anak laki-laki lebih rentan terhadap morbiditas. ${ }^{18}$ Pada penelitian ini menemukan bahwa balita usia diatas 23 bulan cendrung berisiko mengalami stunting.

Upaya percepatan penurunan atau pencegahan stunting dilakukan dalam bentuk intervensi gizi sensitif dan intervensi gizi spesifik. Intervensi gizi spesifik lebih fokus pada upaya pencegahan stunting dalam kurun waktu $1000 \mathrm{HPK}$, meliputi pemberian makanan tambahan untung mengatasi Kekurangan Energi Kronik (KEK) pada ibu hamil, ASI Ekslusif, pemberian tablet tambah darah pada ibu hamil, suplementasi zink, pemberian obat cacing dan vitamin A, menangani gizi buruk dan penanggulangan penyakit infeksi, kelengkapan status imunisasi dasar. Sebagian besar intervensi ini melibatkan tenaga kesehatan serta dapat 


\section{JKM (Jurnal Kebidanan Malahayati),Vol 7,No.4.Oktober 2021, \\ ISSN (Print) 2476-8944 ISSN (Online) 2579-762X, Hal 851-856}

dilakukan di Posyandu dengan koordinasi oleh tenaga kesehatan dari Puskesmas. ${ }^{19,20}$

\section{Hubungan Status Imunisasi Dasar dengan Kejadian Stunting}

Hasil penelitian menunjukan terdapat hubungan antara riwayat status imunisasi dasar pada kejadian balita stunting di Desa Hegarmanah Kecamatan Jatinangor dikarenakan masih banyak ibu dari balita yang belum mengetahui akan pentingnya imunisasi dasar. Gizi yang kurang dan infeksi keduanya dapat bermula dari kemiskinan dan lingkungan yang tidak sehat serta sanitasi yang buruk. Infeksi yang menghambat reaksi imunologis yang normal menghabiskan energi tubuh. Balita yang tidak memiliki imunitas terhadap penyakit, maka akan cepat kehilangan energi tubuh karena penyakit infeksi, sebagai reaksinya adalah menurunnya nafsu makan anak sehingga anak akan menolak untuk makan. Penolakan terhadap makanan berarti berkurangnya pemasukan zat gizi dalam tubuh anak. ${ }^{12}$ Anak akan berisiko stunting jika asupan nutrisinya tidak cukup dan mengalami infeksi berulang. Infeksi berulang pada anak dapat mempengaruhi tumbuh kembangnya sehingga anak akan mudah terserang penyakit. Penyakit memberikan umpan balik yang negatif terhadap status gizi dan jika terjadi dalam jangka waktu yang lama dapat meningkatkan risiko stunting. ${ }^{21}$

Imunisasi dapat menimbulkan antibodi atau kekebalan yang efektif mencegah penularan penyakit tertentu. Pemerintah wajib memberikan imunisasi lengkap kepada setiap bayi. Kemenkes mengubah konsep imunisasi dasar lengkap menjadi imunisasi rutin lengkap. Imunisasi rutin lengkap terdiri dari imunisasi dasar dan lanjutan. Imunisasi dasar lengkap diberikan mulai dari bayi berusia kurang dari 24 jam hingga usia 9 bulan. $^{7}$ Tujuan pemberian imunisasi pada anak untuk mengurangi risiko morbiditas dan mortalitas anak akibat penyakit yang dapat dicegah dengan imunisasi. Status imunisasi pada anak adalah salah satu indikator kontak dengan pelayan kesehatan.

Penelitian ini sejalan dengan penelitian Risna yang menyatakan bahwa status imunisasi memiliki hubungan dengan kejadian stunting pada anak usia 2-5 tahun. ${ }^{22}$ Penelitian lain menyatakan faktor risiko kejadian stunting salah satunya adalah imunisasi dasar dengan OR $(2,921)$ yang artinya memiliki risiko dua kali lebih besar yang mengalami stunting pada balita dengan imunisasi tidak lengkap. ${ }^{23}$ Sejalan dengan penelitian Resti, dkk imunisasi merupakan faktor risiko terhadap kejadian stunting dimana imunisasi dasar tidak lengkap berisiko tiga kali lebih besar untuk menderita stunting dibandingkan dengan balita yang mendapatkan imunisasi dasar lengkap dengan hasil Odds Ratio $(\mathrm{OR})=3,850(\mathrm{Cl} \quad 95 \% \quad 1,358-10,916)$ status imunisasi merupakan faktor risiko kejadian stunting. ${ }^{22} \mathrm{Hal}$ ini sejalan juga dengan penelitian Swathma dkk, yang menyatakan bahwa balita yang tidak mendapatkan imunisasi dasar lengkap berisiko 2,979 kali $(95 \% \mathrm{Cl} 1,372-11,839)$ lebih besar untuk menderita stunting. ${ }^{24}$ Sedangkan beberapa penelitian sebelumnya menyatakan tidak ada hubungan antara status imunisasi dengan kejadian stunting dengan $(p=0,056) .{ }^{12}$

Hasil penelitian menunjukan riwayat status imunisasi dasar memiliki hubungan pada kejadian balita stunting dan berisiko empat kali lebih besar yang mengalami stunting pada balita dengan imunisasi tidak lengkap dengan hasil $(p=0,000) O R$ dan $\mathrm{Cl}(4,958(2,074-11,852))$. Hal ini menyatakan bahwa terdapat hubungan antara riwayat status imunisasi dasar pada kejadian balita stunting di Desa Hegarmanah Kecamatan Jatinangor.

\section{SIMPULAN}

Terdapat hubungan antara riwayat status imunisasi dasar pada kejadian balita stunting di Desa Hegarmanah Kecamatan Jatinangor dengan nilai $p<0,05 \quad(p=0.00<0.05)$ serta terdapat risiko kejadian stunting pada balita dengan imunasi tidak lengkap 4,9 kali dibanding balita dengan imunisasi yang lengkap.

\section{SARAN}

Peneliti selanjutnya diharapkan dapat meneliti lebih lanjut mengenai jenis imunisasi apa yang dapat mempengaruhi stunting.

\section{DAFTAR PUSTAKA}

World Health Organization. Reducing stunting in children: equity considerations for achieving the global targets 2025. WHO. 2018.

Kemenkes RI. Hasil Utama Riset Kesehatan Dasar Tahun 2018. Kementrian Kesehat Republik Indones. 2018.

PKM FK UKI. Gambaran Prevalensi dan Karakteristik Balita dengan Stunting Pada 10 Desa Kabupaten Sumedang Tahun 2018. 2018.

Puskesmas. Data Status Gizi Balita Jatinangor. 2020.

Nurul Khairani SUE. (2019). Family characteristics as risk factors of stunting among children age 12-59 month. Fam Charact as risk factors stunting among Child age 12-59 Mon.4(2). 


\section{Yosintha Dilina Wanda, Fardila Elba, Didah, Ari Indra Susanti,Fedri Ruluwedrata Rinawan}

Adilla Dkk. Pengaruh Stunting terhadap Perkembangan Kognitif dan Prestasi Belajar. Lampung: Fakultas Kedokteran. September 2019;279-280

Dian Nur Hadianti Dkk. Buku Ajar Imunisasi. Jakarta Selatan: Kementerian Kesehehatan RI. September 2015;13

Ilham Dkk. Faktor-Faktor Yang Berhubungan Dengan Kejadian Stunting Pada Baduta Di Wilayah Kerja Puskesmas Buntu Batu Kabupaten Enrekang. Jurnal Kesehatan Masyarakat Mulawarman Vol.1, No.2 Desember 2019 e-ISSN : 2686-3601

Resti Agustia, Nurdin Rahman, Hermiyanty. Faktor Risiko Kejadian Stunting Pada Balita Usia 12-59 Bulan Di Wilayah Tambang Poboya Kota Palu. Ghizda: Jurnal Gixzi dan Kesehatan, 2 (2) 2018, 61 p-ISSN: 26152851 dan e-ISSN: 2622-7622

Hafid F, Nasrul N. Faktor Risiko Stunting Pada Anak Usia 6-23 Bulan di Kabupaten Jeneponto (Risk Factors of Stunting among Children Aged 6-23 Months in Jeneponto Regency). Indonesian Journal of Human Nutrition. 2016.

Resti Agustia, Nurdin Rahman, Hermiyanty. Faktor Risiko Kejadian Stunting Pada Balita Usia 12-59 Bulan Di Wilayah Tambang Poboya Kota Palu. Ghizda: Jurnal Gixzi dan Kesehatan, 2 (2) 2018, 61 p-ISSN: 26152851 dan e-ISSN: 2622-7622

Agung Sutriyawan, dkk. Hubungan Status Imunisasi Dan Riwayat Penyakit Infeksi Dengan Kejadian Stunting Pada Balita. Vol.8 No.2. Journal Of Midwifery.2020

Nadia Nabila Larasati. Faktor-Faktor Yang Berhubungan Dengan Kejadian Stunting Pada Balita Usia 25-59 Bulan Di Posyandu Wilayah Puskesmas Wonosari li Tahun 2017

Hafid F, Nasrul N. Faktor Risiko Stunting Pada Anak Usia 6-23 Bulan di Kabupaten Jeneponto (Risk Factors of Stunting among Children Aged 6-23 Months in Jeneponto Regency). Indonesian Journal of Human Nutrition. 2016.

Altare, C., Delbiso, T. D., Mutwiri, G. M., Kopplow, R., \& Guha-Sapir, D. Factors associated with stunting among pre-school children in Southern Highlands of Tanzania. Journal of Tropical Pediatrics, 62(5), $\quad 390-408 . \quad 2016$ https://doi.org/10.1093/tropej/fmw024
Melati, dkk. Hubungan Berat Badan Lahir Bayi Dengan Kejadian Stunting Pada Balita Di Wilayah Kerja Puskesmas Gunungsari Kabupaten Lombok Barat. Jurnal Kesehatan Qamarul Huda ,Volume 8, Nomor 1 Juni 2020

Torlesse. Determinants of Stunting in Indonesian Children: evidence from a cross-sectional survey indicate a prominent role for the water, sanitation and hygiene sector in stunting reduction. 2016

Chirande. Determinants of stunting and severe stunting among under-fives in Tanzania: evidence from the 2010 cross-sectional household survey. BMC Pediatrics (2015) 15:165. DOI 10.1186/s12887-015-0482-9

Demsa Simbolon. Pencegahan Stunting Melalui Intervensi Gizi Spesifik Pada Ibu Menyusui Anak Usia 0-24 Bulan. In: Pencegahan Stunting Melalui Intervensi Gizi Spesifik Pada Ibu Menyusui Anak Usia 0-24 Bulan. Ed.Ke-1. Yogyakarta: Pustaka Belajar. 2019.

Megawati Ginna, Siska Wiramihardja. Peningkatan Kapasitas Kader Posyandu Dalam Mendeteksi Dan Mencegah Di Desa Cipacing Jatinangor. Dhamakarya. 2019.

Permatasari, D. F., \& Sumarmi, S. Differences of born body length, history of infectious diseases, and development between stunting and non stunting toddlers. Jurnal Berkala Epidemiologi.2018 6 (2), 182-191. https://doi.org/10.20473/jbe.v6i22018.182191

Risna Nur Fajariyah, Atik Choirul Hidajah. Correlation Between Immunization Status And Mother's Height, And Stunting In Children 2-5 Years In Indonesia. Department of Epidemiology, Faculty of Public Health, Universitas Airlangga, Jurnal Berkala Epidemiologi. Surabaya, East Java, Indonesia Vol 8 No 1. 2020

Eti Kurniawati. Faktor Risiko Kejadian Stunting Pada Balita di Kabupaten Kerinci Provinsi Jambi. Volume 2, Nomor 2.eISSN: 26558688.pISSN: 2548-3943Jambi.2020

Vilda Ana Veria Setyawati. Kajian Stunting Berdasarkan Umur dan Jenis Kelamin Di Kota Semarang. Surakarta: University Research Colloqium 2018 STIKES PKU Muhammadiyah Surakarta. 2018 